\title{
THORAX
}

Editorials

\section{Inhaled corticosteroids in COPD: awaiting controlled trials}

Chronic obstructive pulmonary disease (COPD) is an important cause of morbidity and mortality. Recent studies have suggested that mortality from COPD may be still increasing worldwide, especially in the older age groups. ${ }^{1}$ Cigarette smoking is the most important aetiological factor, although genetic predisposition, and occupational and environmental exposures are also implicated. ${ }^{2}$

Epidemiological studies have shown an excessive decline in forced expiratory volume in one second $\left(\mathrm{FEV}_{1}\right)$ in smokers compared with non-smokers ${ }^{23}$ and approximately $15 \%$ of smokers develop symptomatic disease. ${ }^{4}$ The loss of lung function in COPD is greater with increasing age and is related to the initial level of $\mathrm{FEV}_{1}$ and bronchial hyperresponsiveness. ${ }^{56}$ If patients with COPD stop smoking, however, the decline in $\mathrm{FEV}_{1}$ is much less rapid than if smoking had continued. ${ }^{27}$

Smoking cessation is the only currently recognised long term intervention that affects the natural history of $\mathrm{COPD}^{7}$ although the success of smoking cessation programmes is limited. Previous studies examining predictors of mortality in COPD have consistently shown that the most important determinants of survival are the age of the patient and degree of airways obstruction. ${ }^{8}$ Patients with advanced COPD who develop chronic hypoxaemia have improved survival when treated with long term oxygen therapy, ${ }^{10}$ although even then the eventual prognosis is related to the severity of the underlying airways obstruction. ${ }^{11}$ This emphasises the importance of preventing deterioration of lung function in patients with COPD, and the role of long term inhaled corticosteroids in this situation has recently aroused much interest.

\section{Oral corticosteroids in COPD}

Although oral corticosteroids can improve symptoms and lung function in some patients with COPD, ${ }^{12}$ the overall effects have been controversial and the studies reported used relatively short term administration..$^{1314}$ Some of these studies had variable diagnostic labelling and may have included some "asthmatic" patients. Two uncontrolled retrospective studies suggested that oral prednisolone in a daily dose above $7.5 \mathrm{mg}$ may slow the progression of COPD. ${ }^{15}{ }^{16}$ In these studies, however, the beneficial effects on $\mathrm{FEV}_{1}$ were not observed until after a period of at least six months of steroid administration, emphasising that the longer term effects of steroids on airway obstruction in COPD require investigation. These earlier trials used oral steroid dosages that could have serious systemic side effects if used long term, and which might therefore be inappropriate for long term treatment in COPD.

\section{Inhaled corticosteroids in COPD}

Inhaled corticosteroids have an important role in the management of asthma, with improvement in the degree of airways obstruction and bronchial hyperresponsiveness probably related to the reduction of airway inflammation. ${ }^{1718}$ In patients with COPD, however, the results have not been conclusive with respect to change in $\mathrm{FEV}_{1}$, although the majority of studies so far published have used relatively short term inhaled steroid therapy for a period of up to three months. ${ }^{19-24}$ Attempts were made in these studies to identify predictors of improvement but results were variable, perhaps because the numbers of patients studied were small. Inhaled corticosteroids have not shown any significant effect on the level of bronchial hyperresponsiveness in patients with COPD.

The rationale for the use of long term steroids depends on the hypothesis that inflammation of the small airways is instrumental in causing the development of COPD in susceptible smokers. Bronchial biopsy samples from large airways in patients with COPD have shown significantly more inflammatory cells (mainly lymphocytes) than in control subjects, although the total numbers of inflammatory cells in the biopsy samples were lower than in asthmatic patients. ${ }^{25}$ This observation could explain the differences in the effect of steroids on bronchial hyperresponsiveness in COPD and asthma. A recent study of a six week course of inhaled beclomethasone in patients with COPD showed improvement in spirometric values and a fall in bronchial sample cell counts, with decreases in levels of albumin, lactoferrin, and lysozyme as markers of inflammation in the airways. ${ }^{26}$ The changes observed in this study may have been influenced by the fact that these patients had not previously been treated regularly for COPD, and had not previously received steroids.

It is possible that some of the variability in results in earlier studies may have been due to differences in the dose of inhaled steroid administered. In this issue of Thorax, Weir and Burge report the results of a parallel group study in which they compared the effects of a three week treatment with inhaled beclomethasone dipropionate at a dosage of $750 \mu \mathrm{g}$ twice daily with treatment at the higher dosage of $1500 \mu \mathrm{g}$ twice daily in 105 patients with severe COPD without significant reversibility of their airways obstruction to bronchodilators. ${ }^{27}$ The higher dose of inhaled beclomethasone was above the maximum usually recommended for treatment of asthma. Before administration of inhaled steroid, all patients received placebo inhaler and tablets. After the treatment periods with inhaled steroid, two thirds of the patients were treated with oral prednisolone in addition to inhaled steroid while the remainder had placebo tablets plus inhaled 
steroid. In addition to evaluating the effects on airflow, measures of quality of life were performed.

There was a significant improvement in spirometry with the inhaled steroid, but no difference was observed between the two doses studied and there was no additional benefit of the oral steroid. There was also improvement in dyspnoea and some measures of quality of life with inhaled steroid. As in previously published studies, there was no effect on bronchial hyperresponsiveness. Although the mean change in $\mathrm{FEV}_{1}$ for the group overall was only $48 \mathrm{ml}$, approximately one third of the patients in the study were steroid responders as defined by an increase of at least $20 \%$ in lung function compared with baseline values.

The major limitation of this study is that there was no group which received placebo instead of inhaled steroid and thus it is possible that the observations, especially of the subjective measures, may have been due to period effects. This study was short term and the effects of administration of inhaled steroids over a much longer period are more relevant to clinical practice.

\section{LONG TERM THERAPY WITH INHALED CORTICOSTEROIDS IN COPD}

\section{Recent studies}

Two longer term studies on inhaled steroids have recently been reported. ${ }^{28}{ }^{29}$ Dompeling et al compared the effect of inhaled beclomethasone in patients with asthma and COPD over one year. ${ }^{28}$ They found that decline in $\mathrm{FEV}_{1}$ was prevented during the first six months but not during the second six months in both groups, with greater effect in the asthmatic group. This study had no control group and the patients were selected from a previous study of bronchodilator therapy in COPD. ${ }^{30}$ The study population was also unusual in that there were large yearly falls in lung function and thus these results may only apply to patients with COPD with an unusually rapid decline in $\mathrm{FEV}_{1}{ }^{31}$

A Dutch multicentre study examined the effects of adding inhaled steroids to $\beta$ agonist therapy in a relatively young population of patients with airways obstruction comprising both asthma and COPD. ${ }^{29} \mathrm{~A} 10 \%$ improvement in $\mathrm{FEV}_{1}$ over a 2.5 year follow up period was shown, but the patient group was heterogeneous and although the COPD patients showed treatment effects, the major response was in the asthmatic group as expected.

\section{Long term controlled trials in COPD}

The variable results from earlier relatively short term studies emphasise the importance of performing long term trials of inhaled steroid therapy in COPD before regular treatment is recommended. Any long term trials must incorporate careful patient selection to exclude patients with asthma. In addition to investigating carefully any effects on the $\mathrm{FEV}_{1}$, it is important to evaluate changes in quality of life. The studies must also address the safety of long term inhaled steroid treatment, especially with respect to adrenal suppression and bone metabolism, although with conventional doses significant systemic side effects are not likely to occur. ${ }^{32} 33$

Two major trials have now commenced in Europe which are multicentre, double blind, placebo controlled, with parallel groups and will follow patients with COPD for three years. The EUROSCOP study will investigate the effects of inhaled budesonide $400 \mu \mathrm{g}$ twice daily in 1000 cigarette smokers with COPD from 12 countries in Europe. ${ }^{4}$ There is a prolonged run in period during which the patients will be offered a smoking cessation programme before randomisation, and also a check will be made on the degree of the individual patient's compliance with medication. It is expected that an interim analysis will be performed after one year. The second long term trial is investigating the effects of fluticasone in patients with COPD. The results of these two major European studies will be eagerly awaited and will have considerable implications for the management of patients with COPD. It is hoped that these studies, with large patient numbers, will also clarify other important points that have not yet been resolved such as the factors predicting steroid response in COPD. There is already some evidence that there is a subgroup of patients with COPD - those with rapidly declining $\mathrm{FEV}_{1}$ - who may benefit from inhaled steroids ${ }^{28}$ and it would be reasonable to prescribe inhaled steroids to these patients when identified. ${ }^{31}$

Patients with COPD often only come to medical attention when they are disabled with dyspnoea and have developed significant airways obstruction. More emphasis is required on the early detection of abnormal lung function in patients with COPD and definition of relationships between risk factors and pathophysiology of the airways. If any long term therapeutic measure is found to be effective in these patients, early diagnosis and intervention will be imperative. Smoking cessation remains a major objective, as to date this is the most effective way to reduce decline in lung function. It is to be hoped that in future these efforts may lead to a reduction in the considerable morbidity and mortality from COPD.

JA WEDZICHA Consultant Physician, Bonner Road, London E2 $97 X$

Reprint requests to: Dr JA Wedzicha

1 Thom TJ. International comparisons in COPD mortality. Am Rev Respir Dis 1989;140:S27-34.

2 Fletcher C, Peto R, Tinker C, Speizer FE. The natural history of chronic bronchitis and emphysema. An eight year study of early chronic obstructive lung disease in working men in London. Oxford: Oxford University Press, 1976

3 Tager IB, Segal MR, Speizer FE, Weiss ST. The natural history of forced expiratory volumes. Effect of cigarette smoking and respiratory symptoms. Am Rev Respir Dis 1988;138:837-49.

4 Pauwels RA, Lofdahl C-G, Pride NB, Postma DS, Laitinen LA, Ohlsson SV. European Respiratory Society study on chronic obstructive pulmonary disease (EUROSCOP): hypothesis and design. Eur Respir $\mathcal{F}$ 1992;5:1254-61.

5 Postma DS, de Vries K, Koeter GH, Sluiter HJ. Independent influence of reversibility of airflow obstruction and nonspecific hyperreactivity on the longterm course of lung function in chronic airflow obstruction. $A m$ Rev Respir Dis 1986;134:276-80.

6 Burrows B. Predictors of loss of lung function and mortality in obstructive lung diseases. Eur Respir Rev 1991;1:340-5.

7 Camilli AE, Burrows B, Knudson RJ, Lyle SK, Lebowitz MD. Longitudinal changes in forced expiratory volume in one second in adults. Am Rev Respir Dis 1987;135:794-9.

8 Anthonisen NR. Prognosis in chronic obstructive pulmonary disease. Am Rev Respir Dis 1989;140:S95-9.

9 Medical Research Council Working Party. Long term domiciliary oxygen therapy in chronic hypoxic cor pulmonale complicating chronic bronchitis and emphysema. Lancet $1981 ; \mathbf{i}: 681-6$.

10 Nocturnal Oxygen Therapy Trial Group. Continuous or nocturnal oxygen therapy in hypoxaemic chronic obstructive lung disease. Ann Intern Med 1980;93:391-8.

11 Cooper CB, Waterhouse J, Howard P. Twelve year clinical study of patients with hypoxic cor pulmonale given long term domiciliary oxygen therapy. Thorax 1987;42:105-10.

12 Rudd RM. Corticosteroids in chronic bronchitis. BMF 1984;288:1553-4.

13 Mendella LA, Manfreda J, Warren CPW, Anthonisen NR. Steroid response in stable chronic obstructive pulmonary disease. Ann Intern Med 1982;96:17-21.

14 Mitchell DM, Rehan R, Gildeh P, Dimond AH, Collins JV. Effects of prednisolone in chronic airflow limitation. Lancet 1984;ii: 193-6.

15 Postma DS, Steenhuis EJ, van der Weele LTh, Sluiter HJ. Severe chronic airflow obstruction: can corticosteroids slow down progression? Eur $\mathcal{F}$ Respir Dis 1985;67:56-64.

16 Postma DS, Peters I, Steenhuis EJ, Sluiter HJ. Moderately severe chronic airflow obstruction. Can corticosteroids slow down obstruction? Eur Respir f 1988;1:22-6.

17 Jenkins CR, Woolcock AJ. Effect of prednisone and beclomethasone dipropionate on airway responsiveness in asthma: a comparative study. Thorax 1988;43:378-84. 
18 Juniper EF, Kline PA, Vanzieleghem A, Ramsdale EH, O'Byrne PM, Hargreave FE. Effect of long term treatment with an inhaled corticosteroid (budesonide) on airway hyperresponsiveness and clinical asthma in non steroid-dependent asthmatics. Am Rev Respir Dis 1990;142: in non

19 Harding SM, Freedman S. A comparison of oral and inhaled steroids in patients with chronic airways obstruction. Thorax 1978;33: 214-18.

20 Wardman, AG, Simpson FG, Knox AJ, Page RL, Cooke NJ. The use of high dose inhaled beclomethasone dipropionate as a means of assessing steroid responsiveness in obstructive airways disease. $B r F$ Dis Chest steroid responsiven

21 Engel T, Heinig JH, Madsen O, Hansen M, Weeke ER. A trial of inhaled budesonide on airway responsiveness in smokers with chronic bronchitis. Eur Respir f 1989;2:935-9.

22 Weir DC, Gove RI, Robertson AS, Burge PS. Corticosteroid trials in nonasthmatic chronic airflow obstruction: a comparison of oral prednisolone and inhaled beclomethasone dipropionate. Thorax 1990;45: 112-17.

23 Auffarth B, Postma DS, de Monchy JGR, van der Mark ThW, Boorsma M, Koeter GH. Effects of inhaled budesonide on spirometric values, reversibility, airway responsiveness and cough threshold in smokers with chronic obstructive pulmonary disease. Thorax 1991;46:372-7.

24 Watson A, Lim TK, Joyce H, Pride NB. Failure of inhaled corticosteroids to modify bronchoconstrictor or bronchodilator responsiveness in middle-aged smokers with mild airflow obstruction. Chest 1992;101: 350-5.

25 Ollerenshaw SL, Woolcock AJ. Characteristics of the inflammation in biopsies from large airways of subjects with asthma and subjects with chronic airflow limitation. Am Rev Respir Dis 1992;45:922-7.

26 Thompson AB, Mueller MB, Heires AJ, Bohling TI, Daughton D, Yancey SW, et al. Aerosolized beclomethasone in chronic bronchitis. Improved pulmonary function and diminished airway inflammation. $\mathrm{Am}$ Rev Respir Dis 1992;146:389-95.

27 Weir DC, Burge PS. Effects of high dose inhaled beclomethasone dipropionate, $750 \mu \mathrm{g}$ and $1500 \mu \mathrm{g}$ twice daily, and $40 \mu \mathrm{g}$ per day oral prednisolone on lung function, symptoms, and bronchial hyperresponsiveness in patients with non-asthmatic chronic airflow obstruction. Thorax 1993;48:309-316.

28 Dompeling E, van Schayck CP, Molema J, Folgering H, van Grunsven $\mathrm{PM}$, van Weel C. Inhaled beclomethasone improves the course of asthma and COPD. Eur Respir $₹$ 1992:5:945-52.

29 Kerstjens HAM, Brand PLP, Hughes MD, Robinson NJ, Postma DS, Sluiter HJ, et al. A comparison of bronchodilator therapy with or without inhaled corticosteroid therapy for obstructive airways disease. $N$ Engl f Med 1992;327:1413-19.

30 Van Schayck CP, Dompeling E, van Herwaarden CLA, Folgering H, Verbeek ALM, van der Hoogen HJM, et al. Bronchodilator treatment in moderate asthma or chronic bronchitis: continuous or on demand? A randomised controlled study. BMF 1991;303:1426-31.

31 Chung KF. Long-term inhaled corticosteroid therapy in chronic airways obstruction. Eur Respir 7 1992;5:913-14.

32 Geddes DM. Inhaled corticosteroids; benefits and risks. Thorax 1992;47: 404-7.

33 Boe J, Skoogh B-E. Is long-term treatment with inhaled steroids in adults hazardous? Eur Respir f 1992;5:1037-9. 